\title{
Tryptophan diet reduces aggressive behavior in male mice
}

\author{
Julio Cesar Walz ${ }^{1,2}$, Laura Stertz ${ }^{1}$, Adam Fijtman ${ }^{1}$, Bárbara T. M. Q. dos Santos ${ }^{1}$, and Rosa Maria \\ M. de Almeida ${ }^{1}$ \\ 1. Universidade Federal do Rio Grande do Sul, Porto Alegre, RS, Brazil \\ 2. Centro Universitário Unilasalle, Canoas, RS, Brazil
}

\begin{abstract}
A tryptophan diet reduces aggressive behavior in different species, although some controversial findings have been reported. We studied 65 male mice divided into four groups according to increasing dosages of tryptophan $(10,20,30$, and $100 \mathrm{mg} / \mathrm{kg})$ and a control group (vehicle). The first four groups ingested 10,20,30, and $100 \mathrm{mg} / \mathrm{kg}$ tryptophan together with cellulose vehicle and water by gavage before the behavioral tests that sought to record aggressive behavior. The control group received only the vehicle at the same time that the other groups received the tryptophan solutions. The results showed that low concentrations (10 and 20 $\mathrm{mg} / \mathrm{kg}$ ) of tryptophan decreased $(p<.04)$ the frequency of attack bites and lateral threats (i.e., aggressive components; $p<.02)$ after an encounter with a male intruder without altering locomotor activity. In conclusion, the low concentrations of tryptophan diminished aggressive behavior against a male intruder. Keywords: aggression, diet, serotonin, impulsive behavior.
\end{abstract}

Received 05 March 2013; received in revised form 25 July 2013; accepted 03 August 2013. Available online 23 December 2013.

\section{Introduction}

Impulsive aggression is a behavioral disposition characterized by an inability to regulate affect and the impulse to harm oneself or others (Lesch, Araragi, Waider, van den Hove, \& Gutknecht, 2012), and it is highly comorbid with depression, substance use, and suicidal behaviors (Seo, Patrick, \& Kennealy, 2008). In animal models, violence is defined as a form of escalated aggressive behavior that is related to a lack of control (de Almeida, Ferrari, Parmigiani, \& Miczek, 2005; Miczek, de Almeida, Kravitz, Rissman, de Boer, \& Raine, 2007; Miczek, Fish, De Bold, \& De Almeida, 2002). This behavior may be predisposed by serotonin (5-hydroxytryptamine [5-HT]) deficiency in emotion

Julio Cesar Walz, Laura Stertz, Adam Fijtman, and Bárbara T. M. Q. dos Santos, INCT Translational Medicine \& Molecular Psychiatry Laboratory, Hospital de Clínicas de Porto Alegre, Universidade Federal do Rio Grande do Sul, Porto Alegre, Brazil. Rosa Maria M. de Almeida, Instituto de Psicologia do Desenvolvimento e da Personalidade, da Universidade Federal do Rio Grande do Sul (UFRGS), Porto Alegre, RS, Brazil. Laboratório de Psicologia Experimental, Neurociências e Comportamento (LPNeC), Pesquisadora de Produtividade do CNPq. Julio Cesar Walz, Centro Universitário Unilasalle, Canoas, RS, Brazil. Correspondence regarding this article should be directed to: Rosa Maria M. de Almeida, Instituto de Psicologia, Universidade Federal do Rio Grande do Sul, Rua Ramiro Barcelos, 2600, Bairro Santa Cecília Porto Alegre, RS, CEP 90035-003, Brazil. Phone: +55 (51) 3308-5066. Fax: +55 (51) 3308-5470. E-mail: rosa_almeida@yahoo.com or rosa.almeida@ufrgs.br regulation circuitry (New et al., 2002), in addition to the contribution of dopamine hyperfunction to serotonin deficiency (Seo et al., 2008). Furthermore, the dysfunctional relationship between serotoninergic and dopaminergic neurons in the prefrontal cortex may be an important mechanism that connects impulsive aggression to comorbid disorders.

To control aggressiveness, a person's diet may be an important factor. Such behavior can be modulated by supplementation with low doses of tryptophan (Trp). Diets rich in Trp can modulate behavior in various species, including fish (matrinxã Brycon amazonicus; Wolkers, Serra, Hoshiba, \& Urbinati, 2012), sows (Li, Baidoo, Johnston, \& Anderson, 2011), dogs (Bosch, Beerda, Hendriks, van der Poel, \& Verstegen, 2007), horses (Grimmett, \& Sillence, 2005), Wistar rats (Kantak, Hegstrand, Whitman, \& Eichelman, 1980), and mice (Kantak, Hegstrand, \& Eichelman, 1980). Tryptophan deficiency might also lead to an intensification of aggression in several species, including humans (Miczek et al., 2002). This essential amino acid is transported into the brain by a transporter located in the blood-brain barrier (BBB) and acts as a precursor for 5-HT synthesis in neurons. The synthesis of serotonin in the brain is assumed to be proportional to the quantity of Trp transported into the brain (Pardridge, 1998). The levels of this neurotransmitter are essential for the inhibition of aggression (Nelson, \& Chiavegatto, 2001) and can regulate emotion and behavior (Mann, 1995; Virkkunen, Goldman, Nielsen, \& Linnoila, 1995).

Aggressive reactions toward intruders observed in resident males are considered a natural response, 
representing a genetically defined adaptive reaction that seeks to defend territory (Kulikov, \& Popova, 1998; Olivier, \& Young, 2002). Despite the fact that diverse studies have reported a negative correlation between aggression and 5-HT levels in studies that used the resident-intruder paradigm, the results remain contradictory. For example, Mosienko et al. (2012) reported a correlation between enhanced aggression and serotonin deficiency in mice using this paradigm (Mosienko et al., 2012). In contrast, using the same model, Kulikov et al. (2012) reported an opposite correlation between serotonergic activity and aggressive behavior in mice (Kulikov, Osipova, Naumenko, Terenina, Mormède, \& Popova, 2012).

The present study evaluated whether acute oral Trp administration decreases aggressive behavior in male mice subjected to the resident-intruder paradigm.

\section{Materials and Methods}

\section{Animals}

We used 65 adult male and female CF1 strain mice (Mus musculus), weighing 30-40 g. The animals were provided by the State Foundation for Research and Production in Health in Porto Alegre, Brazil, and maintained in compliance with the National Institutes of Health Guide for the Care and Use of Laboratory Animals. All of the animals were kept in a room with controlled temperature $\left(23 \pm 2^{\circ} \mathrm{C}\right), 50-60 \%$ relative humidity, and a $12 \mathrm{~h} / 12 \mathrm{~h}$ light/dark cycle. They were housed in polycarbonate cages $(28 \times 17 \times 14 \mathrm{~cm})$ that were lined with pine shavings. The animals received water and food (ration specific to rodents) ad libitum.

\section{Resident-intruder paradigm}

We used the resident-intruder paradigm to evaluate offensive aggressive behavior. This test is based on the fact that an adult male mouse will establish a territory when given sufficient living space and will attack unfamiliar males that intrude in its home cage (Koolhaas, Coppens, de Boer, Buwalda, Meerlo, \& Timmermans, 2013). Male mice were divided into two groups: residents $(n=65)$ and intruders $(n=80)$. The animals in the intruder group were housed in groups of 10. The animals in the resident group were housed in individual cages accompanied by a female mouse because territoriality is strongly enhanced in the presence of females or sexual experience (Albert, Dyson, Walsh, $\&$ Petrovic, 1988). After a 21-day period of adaptation, each resident mouse was subjected to successive confrontations with an intruder male three times per week, with a minimum interval of $48 \mathrm{~h}$, with the purpose of establishing baseline aggressive behavior. During the test, the female and pups were removed when the male intruder was introduced into the cage. This test lasted 5 min and was recorded with a video camera. Behavior was later analyzed with a computer software program to analyze the previously constructed behaviors. The behavioral repertoire, previously defined by Miczek, \&
O’Donnell (1978), included the frequency of aggressive elements, such as sniffing the intruder, lateral attacks, biting, pursuit, and tail rattling, and the duration of nonaggressive behavior.

When the baseline was establish, the animals were divided into five groups (Vehicle and 10, 20, 30, and 100 $\mathrm{mg} / \mathrm{kg}$ Trp; $n=13$ per group).

\section{Oral tryptophan administration}

Each animal received a dose of $\operatorname{Trp}(10,20,30$, or $100 \mathrm{mg} / \mathrm{kg}$ ) or vehicle by gavage $30 \mathrm{~min}$ before each behavioral test. Tryptophan (Ajinomoto, Japan) was diluted in a solution that contained 5\% carboxymethyl cellulose. The final concentrations of the Trp solution were $1 \%, 2 \%, 3 \%$, and $10 \%$ in a final volume of $30 \mathrm{ml}$. Tryptophan was weighed with the aid of a precision analytical balance and diluted with a magnetic stirrer.

\section{Behavioral test}

Each resident was subjected to successive confrontations with an intruder male. Each session lasted $5 \mathrm{~min}$, twice per week, with a minimum interval of $72 \mathrm{~h}$ for at least 30 days. All of the sessions were recorded for later analyses. The behaviors were analyzed with the aid of computer software (Noldus, Observer, Netherlands) by a trained observer. The frequencies, durations, and temporal and sequential patterns of all of the observed behavioral acts and postures in the combatants during these confrontations were recorded, providing a detailed quantitative assessment of offensive (resident) aggression. Aggressive elements, including frontal attack, side attack, biting the body and head of the intruder, aggressive stance, domination, aggressive cleaning, social investigation, walking, rearing, and grooming, and the frequency and duration of nonaggressive behaviors, including walking, self-cleaning, and standing, were analyzed.

\section{Statistical analysis}

All of the data were homogeneously distributed and are expressed as mean \pm SEM. The effects of different tryptophan concentrations were analyzed using a oneway analysis of variance (ANOVA). Significant effects in the ANOVA $(p<.05)$ were followed by Dunnett's post hoc test to compare the drug treatments with the corresponding vehicle group. All of the statistical analyses were performed using SPSS 18 software.

\section{Results}

\section{Analysis of non-aggressive behavior}

Non-aggressive behaviors, such as walking, rearing, and grooming, were not statistically different compared with the vehicle group (Table 1)

\section{Analysis of aggressive behaviors}

The results showed that the mean frequency of aggressive behavior was significantly different in the 


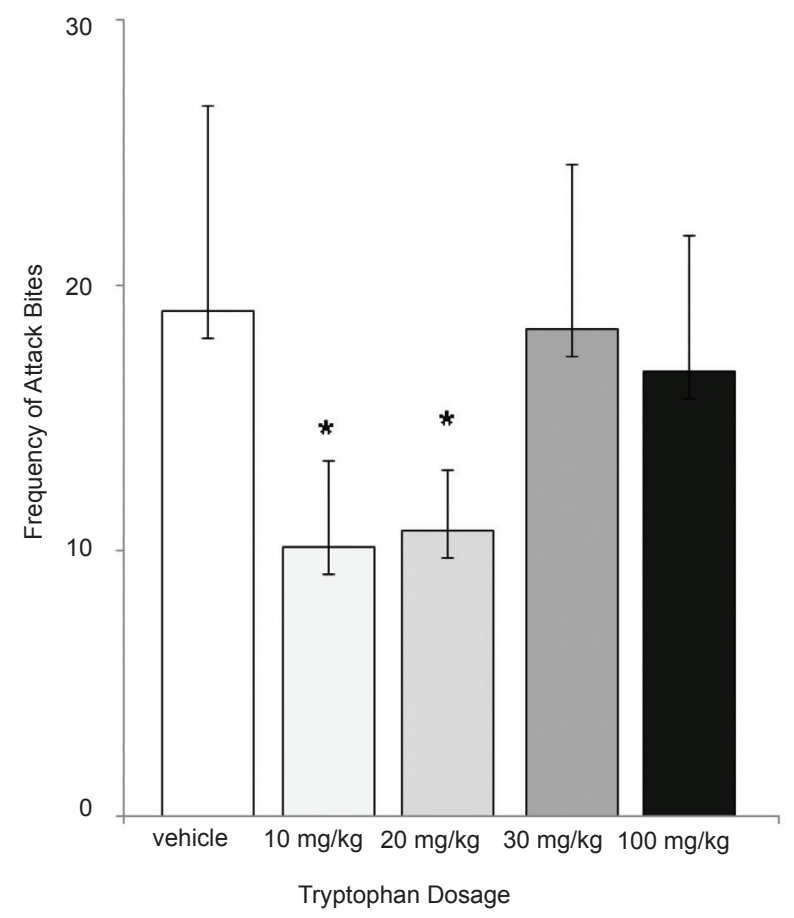

Figure 1. Frequency of attack bites (fighting) in male mice against a male intruder after receiving different concentrations of tryptophan.

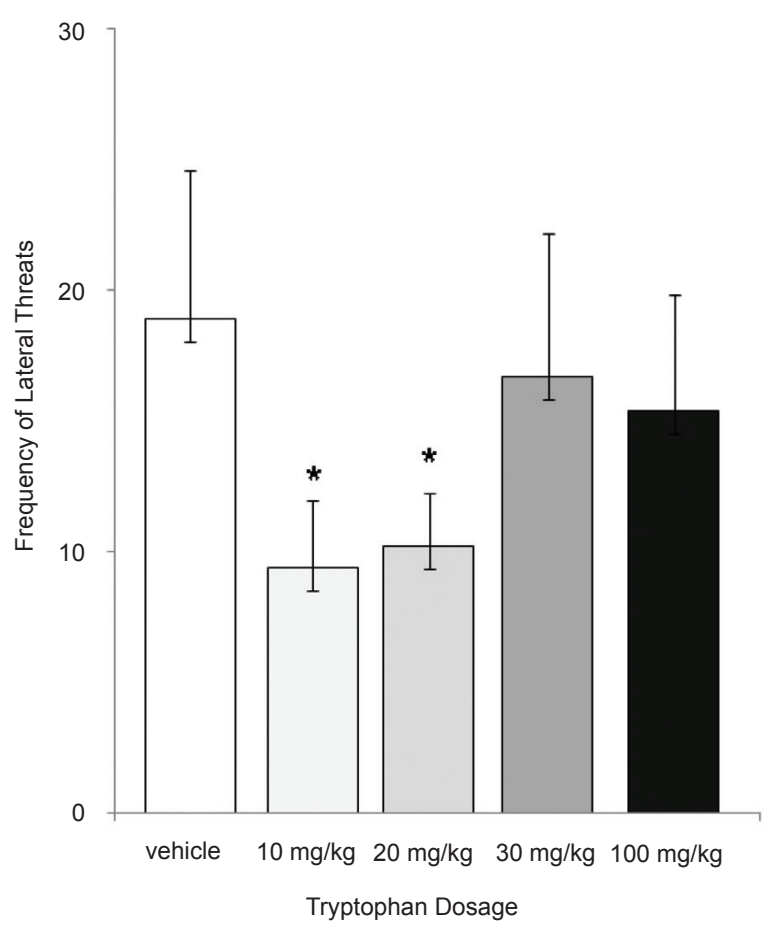

Figure 2. Frequency of lateral threats in male mice against a male intruder after receiving different concentrations of tryptophan.

Table 1. Duration (in seconds) of non-aggressive behaviors in male mice after receiving different concentrations of tryptophan.

\begin{tabular}{llllll}
\hline Frequency & $\begin{array}{l}\text { Vehicle } \\
(\mathbf{n}=\mathbf{1 3})\end{array}$ & $\begin{array}{l}\text { Tryptophan } \\
\mathbf{1 0} \mathbf{~ m g / k g} \\
(\mathbf{n}=\mathbf{1 3})\end{array}$ & $\begin{array}{l}\text { Tryptophan } \mathbf{2 0} \mathbf{~ m g} / \mathbf{k g} \\
(\mathbf{n}=\mathbf{1 3})\end{array}$ & $\begin{array}{l}\text { Tryptophan } \\
\mathbf{3 0} \mathbf{~ m g} / \mathbf{k g}(\mathbf{n}=\mathbf{1 3})\end{array}$ & $\begin{array}{l}\text { Tryptophan } \\
\mathbf{1 0 0} \mathbf{~ m g} / \mathbf{k g}(\mathbf{n}=\mathbf{1 3})\end{array}$ \\
\hline Walking & $72.36 \pm 12.91$ & $60.54 \pm 11.46$ & $65.92 \pm 16.70$ & $62.13 \pm 15.44$ & $61.28 \pm 13.35$ \\
Grooming & $19.13 \pm 6.06$ & $21.51 \pm 6.63$ & $15.44 \pm 3.71$ & $17.28 \pm 7.09$ & $13.64 \pm 3.93$ \\
Sniffing the intruder & $6.46 \pm 2.25$ & $7.38 \pm 1.91$ & $8.10 \pm 2.66$ & $7.28 \pm 2.04$ & $8.03 \pm 1.91$ \\
Rearing & $39.85 \pm 8.77$ & $43.69 \pm 7.33$ & $43.90 \pm 7.30$ & $44.85 \pm 6.53$ & $47.95 \pm 7.21$ \\
\hline
\end{tabular}

Table 2. Frequency of aggressive behaviors in male mice against a male intruder after receiving different concentrations of tryptophan.

\begin{tabular}{|c|c|c|c|c|c|}
\hline Frequency & $\begin{array}{l}\text { Vehicle } \\
(n=13)\end{array}$ & $\begin{array}{l}\text { Tryptophan } 10 \mathrm{mg} / \\
\mathrm{kg} \\
(n=13)\end{array}$ & $\begin{array}{l}\text { Tryptophan } \\
20 \mathrm{mg} / \mathrm{kg} \\
(n=13)\end{array}$ & $\begin{array}{l}\text { Tryptophan } 30 \\
\text { mg/kg } \\
(n=13)\end{array}$ & $\begin{array}{l}\text { Tryptophan } 100 \\
\text { mg/kg } \\
(n=13)\end{array}$ \\
\hline Tail rattle & $19.10 \pm 2.26$ & $17.87 \pm 3.05$ & $18.51 \pm 3.66$ & $17.15 \pm 2.83$ & $15.97 \pm 2.61$ \\
\hline Pursuit & $.10 \pm .10$ & $.10 \pm .10$ & $.28 \pm .20$ & $.12 \pm .12$ & $.17 \pm .14$ \\
\hline
\end{tabular}


animals treated with 10 and $20 \mathrm{mg} / \mathrm{kg}$ Trp compared with the control (vehicle) group. The number of attacks $\left(F_{4,52}=12.27, p=.04\right)$ decreased compared with the vehicle group (Figure 1), with a decrease in the number of lateral threats $\left(F_{4,52}=31.10, p=.02\right.$; Figure $2)$. Other aggressive behaviors, such as tail rattling and pursuit of the intruder, were not significantly different from the control group (Table 2).

\section{Discussion}

The present study tested 10, 20, 30, and $100 \mathrm{mg} / \mathrm{kg}$ concentrations of Trp and analyzed aggression in male mice in a territorial paradigm. We demonstrated that Trp at concentrations of 10 and $20 \mathrm{mg} / \mathrm{kg}$ reduced aggressive behavior in mice, specifically the number of attack bites and lateral threats. These results might indicate the involvement of 5-HT in aggression, mainly because Trp is the precursor for 5-HT in the brain. Importantly, nonaggressive behaviors, such as walking, grooming, and rearing, were not altered by Trp treatment at any of the concentrations, confirming that the differences were not attributable to alterations in locomotor activity.

Manipulating dietary L-tryptophan and consequently 5-HT levels to decrease aggressive behavior is not a recent notion (Kantak et al., 1980; Kantak et al., 1980; Valzelli, 1973; van Hierden, de Boer, Koolhaas, \& Korte, 2004). The first indication that 5-HT can inhibit aggressive behavior came from studies in which neurotoxic agents, such as para-chlorophenylalanine and 5,7-dihydroxytryptamine, decreased the levels of this neurotransmitter. An inverse relationship between 5-HT levels and aggression has been found in both animals and humans (Bjork, Dougherty, Moeller, Cherek, \& Swann, 1999). Most of the results in humans were based on measurements of the main metabolite of serotonin, 5-hydoxyindoleacetic acid (5-HIAA), in cerebrospinal fluid. In animals models, 5-HT and 5-HIAA can be measured directly in the brain, and the inverse relationship between functional serotonergic activity and aggression can be easily established. However, several contradictory results have been found, and one study found a positive relationship between 5-HT and aggression (Kulikov et al., 2012).

Notably, no differences were found at the higher doses of $\operatorname{Trp}$ (30 and $100 \mathrm{mg} / \mathrm{kg}$ ). In mice that received 30 or $100 \mathrm{mg} / \mathrm{kg}$ Trp, the high serotonin levels may have promoted negative feedback through serotoninergic autoreceptors $\left(5-\mathrm{HT}_{1 \mathrm{~A}}\right.$ and $\left.5-\mathrm{HT}_{1 \mathrm{~B}}\right)$, thus diminishing the release of serotonin and consequently enhancing aggressiveness. The overstimulation of presynaptic autoreceptors might lead to autoinhibition of the serotoninergic system through a feedback mechanism (Popova, 2006). Nonetheless, more studies are necessary to clarify this hypothesis. The respective roles of $5-\mathrm{HT}_{1 \mathrm{~A}}$ and $5-\mathrm{HT}_{1 \mathrm{~B}}$ receptors in modulating aggressive behavior remain a source of debate (De Almeida, \& Lucion, 1997; Millan et al., 1997; Mos, Olivier, Poth, Van Oorschot, \& Van Aken, 1993; Sanchez, \& Hyttel, 1994; Sijbesma, Schipper, de Kloet,
Mos, van Aken, \& Olivier, 1991). Consistent with the present results, evidence indicates that the antiaggressive effects of $5-\mathrm{HT}_{1 \mathrm{~A}}$ receptor stimulation are caused by activation of postsynaptic 5-HT receptors (Sijbesma et al., 1991; Mos, Olivier, Poth, \& van Aken, 1992; Mos et al., 1993; Olivier, \& van Oorschot, 2005). Studies with 5-HT $\mathrm{HB}_{1 \mathrm{~B}}$ full and partial receptor agonists, such as CP-94,253, eltoprazine, TFMPP, zolmitriptan, and anpirtoline, have consistently reported antiaggressive effects, regardless of the basal levels of aggressive behavior (de Almeida, \& Miczek, 2002; Miczek et al., 2002; Mos et al., 1992; Olivier, \& Mos, 1986), which may be mediated by somatodendritic autoreceptors (Bannai, Fish, Faccidomo, \& Miczek, 2007) or postsynaptic heteroreceptors (de Almeida, Faccidomo, Fish, \& Miczek, 2001).

Several studies have shown that actions on $5-\mathrm{HT}_{1 \mathrm{~A}}$ and $5-\mathrm{HT}_{1 \mathrm{~B}}$ receptors modulate aggressive behavior, but we believe that $5-\mathrm{HT}_{1 \mathrm{~B}}$ receptors play a primary role in inhibiting aggression. The study by da Veiga, Miczek, Lucion, \& de Almeida (2011) demonstrated a decrease in maternal aggressive behavior after concomitant microinjections of $5-\mathrm{HT}_{1 \mathrm{~B}}$ receptor agonists into the ventral orbital prefrontal cortex and dorsal raphe nucleus in female postpartum rats that were socially instigated, and the activation of these receptors modulated high levels of aggression in a behaviorally specific manner, possibly because of the activation of $5-\mathrm{HT}_{1 \mathrm{~B}}$ receptors at the soma and terminals.

In conclusion, the present findings indicate that low doses of Trp are able to reduce aggressive behavior in male mice in the resident-intruder paradigm. Tryptophan supplementation may be an alternative treatment for aggression in groups that exhibit such behavior. Further studies should test this diet for different periods of time and verify the effects on aggression in different species.

\section{References}

Albert, D. J., Dyson, E. M., Walsh, M. L., \& Petrovic, D. M. (1988). Cohabitation with a female activates testosterone-dependent social aggression in male rats independently of changes in serum testosterone concentration. Physiology and Behavior, 44(6), 735740 .

Bannai, M., Fish, E. W., Faccidomo, S., \& Miczek, K. A. (2007). Anti-aggressive effects of agonists at 5- $\mathrm{HT}_{1 \mathrm{~B}}$ receptors in the dorsal raphe nucleus of mice. Psychopharmacology (Berl), 193(2), 295304.

Bjork, J. M., Dougherty, D. M., Moeller, F. G., Cherek, D.R., \& Swann, A. C. (1999). The effects of tryptophan depletion and loading on laboratory aggression in men: time course and a foodrestricted control. Psychopharmacology (Berl), 142(1), 24-30.

Bosch, G., Beerda, B., Hendriks, W. H., van der Poel, A. F., \& Verstegen, M. W. (2007). Impact of nutrition on canine behaviour: current status and possible mechanisms. Nutrition Research Reviews, 20(2), 180-194.

da Veiga, C. P., Miczek, K. A., Lucion, A. B., \& de Almeida, R. M. (2011). Social instigation and aggression in postpartum female rats: role of 5- $\mathrm{HT}_{1 \mathrm{~A}}$ and $5-\mathrm{HT}_{1 \mathrm{~B}}$ receptors in the dorsal raphe nucleus and prefrontal cortex. Psychopharmacology (Berl), 213(2-3), 475-487. de Almeida, R. M. M., Faccidomo, S., Fish, E., \& Miczek, K. A. (2001). Inhibition of alcohol-heightened aggression by action at post-synaptic 5-HT1b receptors in male mice. Aggressive Behavior, 3, 234-235. 
de Almeida, R. M., \& Lucion, A. B. (1997). 8-OH-DPAT in the median raphe, dorsal periaqueductal gray and corticomedial amygdala nucleus decreases, but in the medial septal area it can increase maternal aggressive behavior in rats. Psychopharmacology (Berl), 134(4), 392-400.

de Almeida, R. M., \& Miczek, K. A. (2002). Aggression escalated by social instigation or by discontinuation of reinforcement ("frustration") in mice: inhibition by anpirtoline: a $5-\mathrm{HT}_{1 \mathrm{~B}}$ receptor agonist. Neuropsychopharmacology, 27(2), 171-181.

de Almeida, R. M., Ferrari, P. F., Parmigiani, S., \& Miczek, K. A. (2005). Escalated aggressive behavior: dopamine, serotonin and GABA. European Journal of Pharmacology, 526(1-3), 51-64.

Grimmett, A., \& Sillence, M. N. (2005). Calmatives for the excitable horse: a review of L-tryptophan. Veterinary Journal, 170(1), 24-32.

Kantak, K. M., Hegstrand, L. R., \& Eichelman, B. (1980). Dietary tryptophan modulation and aggressive behavior in mice. Pharmacology Biochemistry and Behavior, 12(5), 675-679.

Kantak, K. M., Hegstrand, L. R., Whitman, J., \& Eichelman, B. (1980). Effects of dietary supplements and a tryptophan-free diet on aggressive behavior in rats. Pharmacology Biochemistry and Behavior, 12(2), 173-179.

Koolhaas, J. M., Coppens, C. M., de Boer, S. F., Buwalda, B., Meerlo, P., \& Timmermans, P. J. A. (2013). The resident-intruder paradigm: a standardized test for aggression, violence and social stress. Journal of Visualized Experiments, 77.

Kulikov A, \& Popova, N. (1998). Association between intermale aggression and genetically-defined tryptophan hydroxylase activity in the mouse brain. Aggressive Behavior, 22(2), 111-117.

Kulikov, A. V., Osipova, D. V., Naumenko, V. S., Terenina, E., Mormède, P., \& Popova, N. K. (2012). A pharmacological evidence of positive association between mouse intermale aggression and brain serotonin metabolism. Behavioural Brain Research, 233(1), 113-119.

Lesch, K. P., Araragi, N., Waider, J., van den Hove, D., \& Gutknecht, L. (2012). Targeting brain serotonin synthesis: insights into neurodevelopmental disorders with long-term outcomes related to negative emotionality, aggression and antisocial behaviour. Philosophical Transactions of the Royal Society of London B Biological Sciences, 367(1601), 2426-2443.

Li, Y. Z., Baidoo, S. K., Johnston, L. J., \& Anderson, J. E. (2011). Effects of tryptophan supplementation on aggression among group-housed gestating sows. Journal of Animal Sciences, 89(6), 1899-1907.

Mann, J. J. (1995). Violence and aggression. In F.E. Bloom, D.J. Kupfer (Eds.), Psychopharmacology: the fourth generation of progress (pp. 1919-1928). New York: Raven Press.

Miczek, K. A., \& O’Donnell, J. M. (1978). Intruder-evoked aggression in isolated and nonisolated mice: effects of psychomotor stimulants and L-DOPA. Psychopharmacology (Berl), 57(1), 47-55.

Miczek, K. A., de Almeida, R. M., Kravitz, E. A., Rissman, E. F., de Boer, S. F., \& Raine, A. (2007). Neurobiology of escalated aggression and violence. Journal of Neuroscience, 27(44), 1180311806.

Miczek, K. A., Fish, E. W., De Bold, J. F., \& De Almeida, R. M. (2002). Social and neural determinants of aggressive behavior: pharmacotherapeutic targets at serotonin, dopamine and $\gamma$-aminobutyric acid systems. Psychopharmacology (Berl), 163(34), 434-458.

Millan, M. J., Hjorth, S., Samanin, R., Schreiber, R., Jaffard, R., De Ladonchamps, B., Veiga, S, Goument, B., Peglion, J. L., Spedding, M., \& Brocco, M. (1997). S 15535, a novel benzodioxopiperazine ligand of serotonin (5-HT)1A receptors: II. Modulation of hippocampal serotonin release in relation to potential anxiolytic properties. Journal of Pharmacology and Experimental Therapeutics, 282(1), 148-161.

Mos, J., Olivier, B., Poth, M., \& van Aken, H. (1992). The effects of intraventricular administration of eltoprazine, 1-(3-trifluoromethylphenyl)piperazine hydrochloride and 8-hydroxy-2-(di-n-propylamino)tetralin on resident intruder aggression in the rat. European Journal of Pharmacology, 212(23), 295-298.

Mos, J., Olivier, B., Poth, M., Van Oorschot, R., \& Van Aken, H. (1993). The effects of dorsal raphe administration of eltoprazine, TFMPP and 8-OH-DPAT on resident intruder aggression in the rat. European Journal of Pharmacology, 238(2-3), 411-415.

Mosienko, V., Bert, B., Beis, D., Matthes, S., Fink, H., Bader, M., \& Alenina, N. (2012). Exaggerated aggression and decreased anxiety in mice deficient in brain serotonin. Translational Psychiatry, 2, e122.

Nelson, R. J., \& Chiavegatto, S. (2001). Molecular basis of aggression. Trends in Neurosciences, 24(12), 713-719.

New, A. S., Hazlett, E. A., Buchsbaum, M. S., Goodman, M., Reynolds, D., Mitropoulou, V., Sprung, L., Shaw, R. B., Jr., Koenigsberg, H., Platholi, J., Silverman, J., \& Siever, L. J. (2002). Blunted prefrontal cortical 18fluorodeoxyglucose positron emission tomography response to meta-chlorophenylpiperazine in impulsive aggression. Archives of General Psychiatry, 59(7), 621-629.

Olivier, B., \& Young, L. (2002). Animal models of aggression. In K.L. Davis, D. Charney, J.T. Coyle, \& C. Nemeroff (Eds), Neuropsychopharmacology: the fifth generation of progress (pp. 1699-1708). Philadelphia: Lippincott Williams and Wilkins.

Olivier, B., \& Mos, J. (1986). Serenics and aggression. Stress Medicine, 2(3), 197-209.

Olivier, B., \& van Oorschot, R. (2005). 5-HT ${ }_{1 \mathrm{~B}}$ receptors and aggression: a review. European Journal of Pharmacology, 526(1-3), 207-217.

Pardridge, W. M. (1998). Blood-brain barrier carrier-mediated transport and brain metabolism of amino acids. Neurochemical Research, 23(5), 635-644.

Popova, N. K. (2006). From genes to aggressive behavior: the role of serotonergic system. Bioessays, 28(5), 495-503.

Sanchez, C., \& Hyttel, J. (1994). Isolation-induced aggression in mice: effects of 5-hydroxytryptamine uptake inhibitors and involvement of postsynaptic 5-HT $1 \mathrm{~A}$ receptors. European Journal of Pharmacology, 264(3), 241-247.

Seo, D., Patrick, C. J., \& Kennealy, P. J. (2008). Role of serotonin and dopamine system interactions in the neurobiology of impulsive aggression and its comorbidity with other clinical disorders. Aggressive and Violent Behavior, 13(5), 383-395.

Sijbesma, H., Schipper, J., de Kloet, E. R., Mos, J., van Aken, H., \& Olivier, B. (1991). Postsynaptic 5-HT1 receptors and offensive aggression in rats: a combined behavioural and autoradiographic study with eltoprazine. Pharmacology Biochemistry and Behavior, 38(2), 447-458.

Valzelli, L. (1973). The "isolation syndrome" in mice. Psychopharmacologia, 31(4), 305-320.

van Hierden, Y. M., de Boer, S. F., Koolhaas, J. M., \& Korte, S. M. (2004). The control of feather pecking by serotonin. Behavioral Neuroscience, 118(3), 575-583.

Virkkunen, M., Goldman, D., Nielsen, D. A., \& Linnoila, M. (1995). Low brain serotonin turnover rate (low CSF 5-HIAA) and impulsive violence. Journal of Psychiatry and Neuroscience, 20(4), 271-275.

Wolkers, C. P., Serra, M., Hoshiba, M. A., \& Urbinati, E. C. (2012). Dietary L-tryptophan alters aggression in juvenile matrinxã Brycon amazonicus. Fish Physiology and Biochemistry, 38(3), 819-827. 